\title{
Modern Western Philosophy in the Liberal Education in Current English Majors' Language Teaching in China ${ }^{*}$
}

\author{
REN Rui, LIU Zhuo, ZHENG Ya-li \\ Northeastern University, Shenyang, China
}

\begin{abstract}
In recent years, liberal education has been a focus of English majors' education in China. Although it was wished and emphasized, there are many problems and difficulties when liberal education is asked to be achieved in the real sense. English majors' liberal education is yet at its primary stage. An analysis of the existing problems is made on the basis of the situation and characteristics of current English majors' education.
\end{abstract}

Keywords: liberal education, English majors, China

\section{Introduction}

“人文教育” has been a popular topic in the higher education in China (XIE, 2011). To use "humanistic education” to mean “人文教育” is now found common in China's searchers like Baidu when “人文教育” is searched. However, it turns out to be a misuse. According to Wikipedia, humanistic education (also called person-centered education) refers to an approach to education based on the work of humanistic psychologists and humanistic pedagogues. Undoubtedly, people need to be suggested not to confuse humanistic education with liberal arts education.

Liberal education or general education turns out to be better choices when referring to improve students' liberal arts knowledge in English majors' education. Also cited from Wikipedia,

A liberal education is a system or course of education suitable for the cultivation of a free (Latin: liber) human being. It is based on the medieval concept of the liberal arts or, more commonly now, the liberalism of the Age of Enlightenment. It has been described as a philosophy of education that empowers individuals with broad knowledge and transferable skills, and a stronger sense of values, ethics, and civic engagement...characterised by challenging encounters with important issues, and more a way of studying than a specific course or field of study by the Association of American Colleges and Universities. Usually global and pluralistic in scope, it can include a general education curriculum which provides broad exposure to multiple disciplines and learning strategies in addition to in-depth study in at least one academic area. ${ }^{1}$

\footnotetext{
* Acknowledgements: This research is funded by Education Department, Liaoning Province, China. Project of Humanities and Social Sciences (No. W2012038). It is also funded by 2014-NEU (Northeastern University, China) Research Project of College Education, Teaching and Reform (No. 48). Both projects are headed by REN Rui. It is funded by the Project of UPRP20140421, which is headed by ZHANG Yan-nan.

REN Rui, associate professor, master, English Department, Northeastern University. Doctor candidate of Foreign Philosophy at School of Philosophy and Society, Jilin University.

LIU Zhuo, professor, master degree, English Department, Northeastern University.

ZHENG Ya-li, postgraduate, English Department, Northeastern University.

${ }^{1}$ See http://en.wikipedia.org/wiki/Liberal_education.
} 
Liberal education has been of heated discussion and part of present high education reforms of different kinds, especially in current English majors' language teaching. Interestingly, liberal education is not entirely new and also not entirely old, since traces of liberal education could be found in current courses of English majors, such as "Bible Stories" and "Ancient Greek and Roman Mythologies". Hence, the problem lies in inadequate liberal education in the current language teaching of English majors and how to solve it.

\section{Inadaquate Liberal Education in Current English Majors' Language Teaching}

The inadaquate liberal education is a fact in current English majors'education,which is well-recognized among Chinese English teachers (FENG, 2012; ZHANG, 2013; ZHU, 2013). Such a fact makes teachers of English majors in China have no hand to make a fist or cannot make sticks without straw. They are worried about students' lack of liberal knowledge. But they could do nothing due to the current curriculum.

Generally, in current English majors' language teaching, there are three problems concerning the inadequate liberal education.

First, little has been done in the design of curriculum. Most curricula of English majors in China are teemed with a great variety of skill-oriented courses, such as Intensive Reading and Extensive Reading, Listening, Writing, and Translation together with Introduction to American and British Literature or the Survey of Britain and America. It is true that current courses like the above could provide English majors with some basic liberal knowledge. The problem does not lie in the existence of the liberal knowledge but in the extent or coverage. It has been proved that the liberal knowledge that students could have acquired from courses like Literature or text of Intensive Reading, Extensive Reading, and Listening, is too limited to meet the demands of liberal communication in reality. A common phenomenon is that even English majors have little to continue a talk with a foreigner, native or not. The talk could start with greetings, but it could also stop just by the greetings since little could be discussed other than greetings. The failure of educating English majors in terms of liberal education is just an annoying fact confronting current English language educators in the tertiary level.

Second, a relative result is that the single emphasis on skill-oriented courses unavoidably leads to shortage of liberal education. Old curriculum of English majors is utterly skill-oriented. As a result, English majors could speak fluent English. However, an eminent problem is that their language tends to be beautiful in sound but not in content. One's language without ideas are just like people without souls.

Third, some educators have recognized that liberal education is important. However, another problem that comes after is that they try to enhance humanism in the existent courses. In another, importance of educating humanism is attached to language teaching in the already existent classes like reading, listening,writing, and translation. Such a practice is no more than catching fish by climbing trees, which is essentially no difference from the old teaching. Restricted by the old courses, English teachers could do little to fundamentally change their students knowledge system. Therefore, opening special liberal courses is the very solution to the current shortage of liberal education in English majors language teaching.

\section{Suggested Tentative Ways of Liberal Education in the Current Teaching: Similar to Climbing a Tree to Catch Fish}

Inadaquate liberal education in English majors' langauge teaching is shared by all the scholars who have 
published their studies with regard to liberal education. However, the solutions to the situation are to be taken into consideration. Currently, the suggested tentative ways of liberal education in China are at its "theoretical" stage or slogan-stage, which can be classified as the following three:

(1) Way of urging teachers to promote liberal education in traditional courses. It is thought that liberal education could be achieved by teachers enlarging vocabulary or cultural notes;

(2) Way of urging teachers to develop their potentials in liberal education. Liberal knowledge is not a potential that can be developed by "digging";

(3) Way of intending to quest for liberal education from the current curriculum is by no means possible. It is just like trying fishing in the air.

"Climb a tree to catch fish" is most commonly termed as "fish in the air". However, climbing a tree to catch fish is more preferred since it is a simile can be used here to describe vividly the current condition of Chinese English majors' liberal education. The condition is like climbing a tree to catch fish. "Tree" refers to the current way of educating English majors. "Fish" refers to the liberal knowledge of English majors, which is part of the very quality education that has been yearned for and wished by Chinese tertiary educationers in recent years.

\section{English in the Real Sense of One Subject of Liberal Arts: Fishing Fish in the Sea}

English should be taught in the sense of English as part of liberal arts. When touching on liberal education, what liberal arts covers should be included in the courses of English majors'. One course to mean liberal education is impossible. Instead, a series of Western cultural courses should be included in terms of liberal or general education. What is vital is that all Western cultures should be included those of cultures ranging from English-speaking countries to none-English-speaking countries. For instance, philosophy is one of the basics to be taught.

When English is taught just as one subject of liberal arts, it is not a skill any longer. To be exact, it is not "instrumental" as most commonly mentioned in Chinese college English curriculum. Language as English is rich and profound, which should not be defined only as skills of listening, speaking, reading, writing, and translation. Thought in English should be the most essential knowledege. Liberal arts courses in Higher Education, particularly in English majors' college English is the real solution to the dilema of the current English majors teaching in Chinese universities. The philosophy courses should include both Oriental philosohy and Western philsophy. First, introduction to Western philosophers' philosophies should be the most important part in the liberal education, in which thoughts and works of individual philosophers should be emphasized. Since such an education of philosophy is common in the European countries and countries in the Americas. In order to communicate with English speakers, Western philosophy is a must. If Chinese college students are familiar with the Western philosophers, then there is much they exchange with foreigners in English. In the meanwhile, Oriental philosophy is of the same importance, especially Chinese philosophy. To have knowledge of the Chinese philosophy is part of the obligation of every Chinese. Higher Education in China should cover both Western and Oriental philosophy. In particular, English majors need to be equipped with sound and profound cultural knowledge of both Western and Oriental philosophy, which should be the definition of the liberal education in English majors' curriculum. 
Luckly, such a viewpoint of establishing a series of western cultural courses was put forward by some scholars. In 2013, ZHA Ming-jian delivered two speeches stressing the education of English as a subject in itself. He mentioned the importance of "liberal general education" and pointed out that concepts of a subject determine corresponding concepts of intellect cultivation, teaching goals, and teaching systems and models. English should go back to the origin as a liberal subject, which is part of liberal arts. English as a subject, it should not be depicted as being pragmatic and instrumental. In his speech in Xi'an on August 8, 2013, he pointed that,

The major of English should not be mistaken as learning everything in and within English only, the real appropriate understanding of the major should by means of English learn all knowledge concerning liberal arts, social and scientific knowledge all over the world. The language teaching of English majors should teach students all studies and English is the language to be used. Teaching English majors English means teaching students liberal or general knowledge in English. For example, the Course of "Bible Stories" should be improved as "Bible and the Western Culture", "Ancient Greek and Roman Mythologies", as "Ancient Greek and Roman Mythologies and the Western Culture", other course like British and American Society and Culture, World Culture, Chinese Culture, the Comparison and Contrast of Chinese and Western Cultures, Cross-cultural Studies, Translation Studies, Western Philosophies, History of Western Civilization, and History of Western Arts. ${ }^{2}$

In his speech on October 20, 2013, he advised modern English teaching should follow the tradition of general education-oriented English teaching like what was done by the first English educators in Tsinghua University in 1930s and 1940s.

To sum up, the above suggestions by ZHA (2013) are constructive, but it is not enough. These courses are still restricted by the old curriculum of English majors. Shadows of old courses could be seen as the suggested new ones.

A entirely thorough and liberal education in the real sense should be courses taught not from the perspective of an English teacher but from the perspective of the subject it itself. Take philosophy as an example, it should be taught from the perspective of a philosophy teacher in English but not that of an English teacher in English. Every subject is typical in its own sense. If these course are taught in English, they should be taught by teachers of corresponding subjects. If they are taught by English teachers without correponding training, the courses could by no means in the real sense of liberal education. And, again, fish is searched by climbing a tree. So, if English Department faculty do not have teachers who have furthered their studies by interdiscipline learning, such liberal education courses are suggested to be taught by teacher from the department of philosophy, college of arts, and so on. Only in this way could liberal education of English majors be achieved. Students' knowledge could be broadened in the real sense.

\section{Modern Western Philosophy Knowledge: An Amendament and Wayout}

English should be taught in the sense of English as part of liberal arts. When touching on liberal education, modern western philosophy should have been a necessary part in current English majors' teaching, which is both an amendament and the very wayout. First of first, it could be an amendament. Traditional English majors' teaching is by no means immune of libreal education since there already have been courses involving Bible and Surveys of British and American Cultures. However, it is not liberally general enough to make English majors' knowledge system full. Modern western philosophy is basic for European and American high school students.

\footnotetext{
${ }^{2}$ See http://learning.sohu.com/20131030/n389229556.shtml.ppt.
} 
Modern western philosophy is the wayout for current English majors' teaching integral when English is taken as a liberal art subject. Having knowledge of modern Western philosophy could make English majors in China have as a sound knowledge system as that of the youngsters in the Western World.

\section{Conclusion}

First of first, fish in the air is by no means possible. Liberal education needs to be achieved by opening courses such as Introduction to Western Thought, Mythology, Bible Stories, and so on. The key of solving problems in current English majors' liberal education is how to fish in the water or make a wife/housewife cook with rice. If English majors are required to have liberal arts knowledge, liberal education courses should be opened up. In order to have liberal education courses, teachers need to be equipped with liberal arts knowledge themselves. In another word, they need to be educated first, then could they teach liberal courses and educate English majors. Otherwise, corresponding subjects teachers should be invited to the English Department to teach courses such as philosophy and arts.

\section{References}

FENG, Z. M. (2012). The urgency and ways of liberal education in higher education english classes in the era of globalization. Time Report (2nd half of the month), 2(2), 6-7.

Humanistic education. (n.d.). In Wikipedia. Retrieved from http://en.wikipedia.org/wiki/Humanistic_education

Liberal education. (n.d.). In Wikipedia. Retrieved from http://en.wikipedia.org/wiki/Liberal_education

XIE, H. P. (2011). Developing Chinese culture, enhancing the cultivation of liberal arts qualities. Journal of Qiush, 17, 55-56.

ZHA, M. J. (2013). The expertise of the subject English and the cultivation reformation in terms of liberal arts qualities. Retrieved from http://learning.sohu.com/20131030/n389229556.shtml.ppt

ZHANG, X. N. (2013). The research of liberal arts education in College English intensive reading. Journal of Qiqihar Junior Teachers'College, 153(5), 151-152.

ZHU, H. Y. (2013). The cultivation of liberal arts qualities in English majors' teaching. Journal of Chendu Normal University, 29(6), 57-61. 